\title{
Aktinomikozis Nedenli Apandisit Olgusu
}

\section{Özben Yalçın', Süleyman Özdemir², Uygar Demir ${ }^{3}$, Sinan Ömeroğlư ${ }^{4}$, Fevziye Kabukçuoğlư ${ }^{5}$}

ÖZET:

Aktinomikozis nedenli apandisit olgusu

Aktinomikozis aktinomiçes tarafından oluşturulan bir enfeksiyondur. Abdominal enfeksiyonlar genellikle mukozal bütünlüğün bozulduğu durumlarda oluşmaktadır. Bu olgu sunumunda, akut apandisit tanısı almış cerrahi sonrası tanısı konulan aktinomikoz olgusu ve aktinomikoz hakkında genel bilgiler kısaca sunulmaktadır.

Anahtar kelimeler: Aktinomikoz, akut apandisit

\section{ABSTRACT:}

Appendicitis caused by actinomycosis: a case study

Actinomycosis is an uncommon suppurative infection. The Actinomyces species can cause opportunistic infections due to the disruption of the mucosal surface. We report a case initially presented as acute appendicitis and definitely diagnosed as actinomycosis after surgery and short summary of the general knowledge on actinomycosis.

Key words: Actinomycosis, acute appendicitis

Ş.E.E.A.H. Tıp Bülteni 2015;49(3):221-3

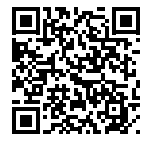

${ }^{1}$ Uzm. Dr., ${ }^{2} A$ sist. Dr., ${ }^{5}$ Doç. Dr., Şişli Hamidiye Etfal Ĕgitim ve Arastırma Hastanesi,

Patoloji Bölümü, istanbul - Türkiye

${ }^{3} U z m$. Dr., ${ }^{4}$ Asist. Dr., Şişli Hamidiye Etfal Eğitim ve Araştırma Hastanesi, Genel Cerrahi Bölümü, İstanbul - Türkiye

Yazışma Adresi / Address reprint requests to: Uzm. Dr. Özben Yalçın,

Şişli Hamidiye Etfal Eğitim ve Araştırma Hastanesi, Patoloji Bölümü, İstanbul - Türkiye

Telefon / Phone: +90-212-373-5000/5016

E-posta / E-mail: ozbena@yahoo.com

Geliş tarihi / Date of receipt: 10 Ekim 2014 / October 10, 2014

Kabul tarihi / Date of acceptance: 18 Mart 2015 / March 18, 2015

\section{Giriș}

Aktinomikozis; gram pozitif, anaerobik bir bakteri olan aktinomices tarafından ağız, kolon ve vajen florasını etkileyen bir enfeksiyondur. Sülfür granüllerinin biyopsi materyalinde saptanması ile tanı konulmaktadır (1). Bu olgu sunumunda hastanemizde akut apandisit nedeniyle opere edilmiş olan ve ancak cerrahi işlem sonrası histopatolojik incelemeyle tanı konulabilmiş bir mukozal aktinomices kolonizasyonu olgusu sunulmuştur.

\section{OLGU}

Öncesinde bilinen bir öyküsü olmayan 32 yaşında erkek hasta iki gün öncesi epigastrik bölgede başlamış, ertesi gün sağ alt kadrana yayılmış karın ağrısı ve artan iştahsızlık şikayeti ile acil servise başvurdu. Fiziksel muayenesinde sağ alt kadranda defans ve rebound saptandı. Karın ultrasonografisinde batın sağ alt kadranda inflamasyon ile uyumlu ekojenite artışı, batın tomografisinde batın sağ alt kadranda çekumdan başlayıp posteriorda derin plana doğru uzanım gösteren ve kör uçta sonlanan yaklaşık 12 $\mathrm{mm}$ boyutunda akut apandisit ile uyumlu tübüler bağırsak ansı çevresinde minimal sıvı ve inflamasyonu destekleyen mezenterik dansite artışı görüldü. Laboratuvarında beyaz küre; $16.000 / u L$ ve serum C-reaktif protein $29,41 \mathrm{mg} / \mathrm{dL}$ idi. Laparotomi ile retroçekal yerleşimli, ödemli, inflame ve çevre dokulara yapışık appendiks çıkarıldı. Olgunun appendektomi materyalinden hazırlanan preparatların mikroskopik incelemesinde appendiks duvarında yoğun fibrozis, lümende ve mukozada aktinomikoz kolonisi ve sülfür granülleri görüldü (Resim 1). Uygulanan histokimyasal boyalar PAS ve PAS-M ile mikroorganizmalar boyandı aktinomikozis tanısı kondu (Resim 2). íki hafta parenteral penisilin G (18mU/gün), bitiminde iki ay süre ile oral penisilin verildi. Hasta sorunsuz olarak izlenmektedir. 


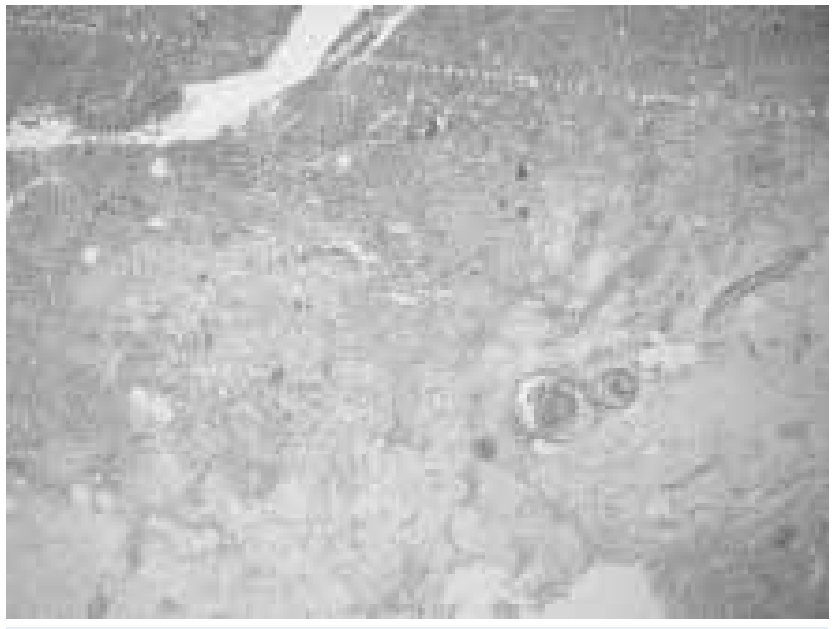

Resim 1: Actinomyces kolonileri (*) (HE ile boyama, $\times 10$ )

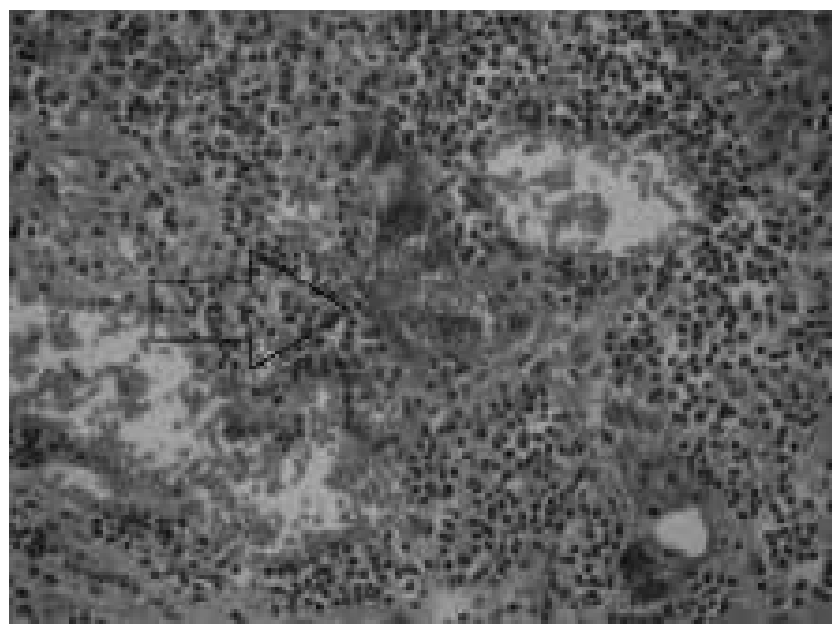

Resim 2: Actinomyces kolonileri (*) (HE ile boyama, $\times 40$ )

\section{TARTIŞMA}

Aktinomikoz, mikroaerofilik anaerop Grampozitif bakterilerin neden olduğu kronikleşen, fistül oluşumuna neden olabilen ve infiltrative yayılabilen bir hastalıktır (1). İnsanda aktinomikoza neden olabilen birçok Actinomyces türü olmasına rağmen hastaIığın \%75-95'i A. İsraelii tarafından oluşturulur $(1,2)$. Actinomyces'ler, mukozanın normal endojen florası olup mukoza bütünlüğü bozulmadıkca giriş kapısı bulamazlar (3). Bizim vakamızda da akut apandisit sırasında hasar görmüş muskularis propriada karakteristik koloniler görüldü. Oluşan hastalık da genellikle mikst etken görülür.

Aktinomikozlar en sık \%55 oranla servikofasiyal

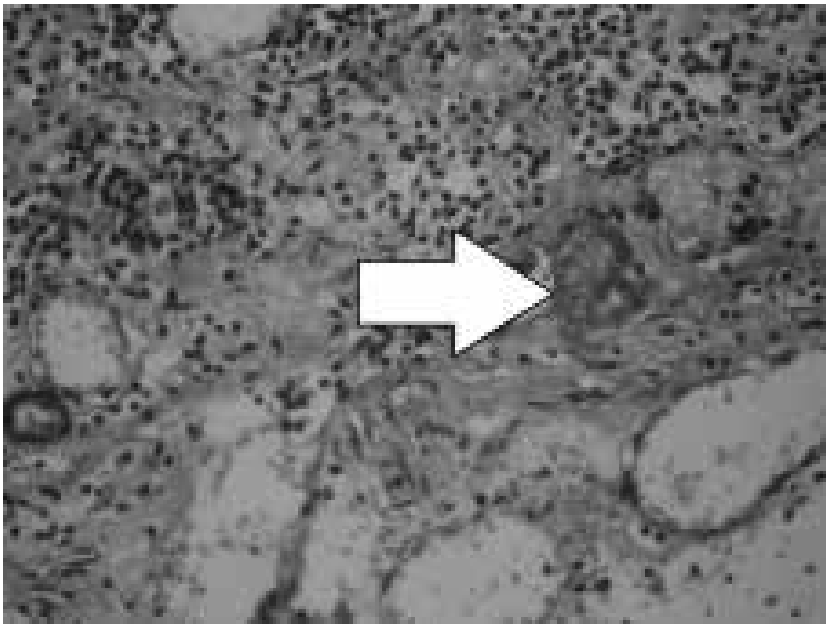

Resim 3: Actinomyces kolonileri (*) (PAS ile boyama, $\times 40$ )

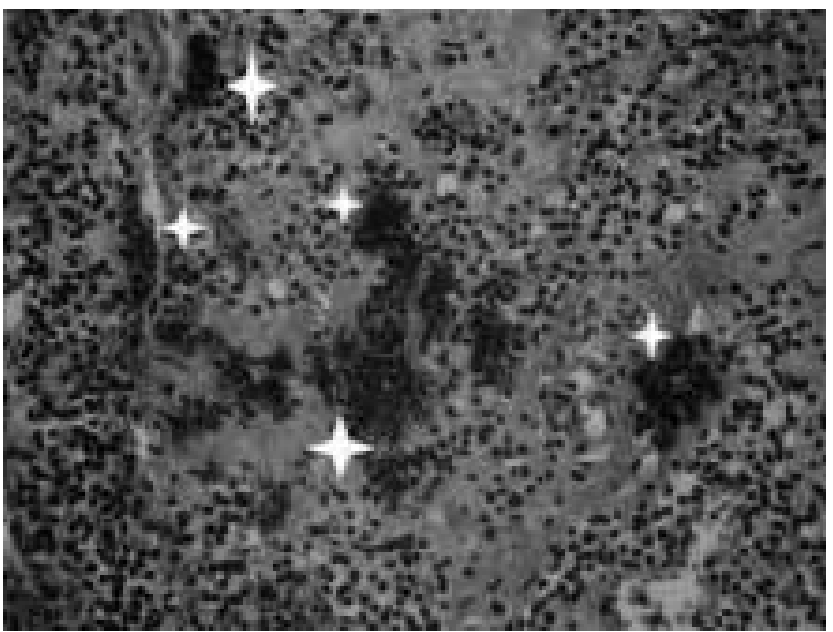

Resim 4: Actinomyces kolonileri (*) (PAS ile boyama, $\times 40$ )

yerleşimli olmakla beraber torasik, abdominal, pelvik, dissemine ve merkezi sinir sistemine yerleşen klinik formları da vardır (1-3). Gastrointestinal sistemde en sık ileokolik bölgede yerleşir. Gastrointesinal cerrahi ya da apandisit sonrasında intraabdominal hastalık olarak ortaya çıkabilmektedir. Bazen vakamızdaki gibi primer akut apandisit olgularında da mukoza ve periapandiküler alanda insidental görülebilirler. Tedavisiz olgularda abdominal apselere neden olabilirler. Görüntüleme genellikle nonspesifiktir. Kronikleşmiş vakalarda görüntülemede apse ya da infiltratif kitle görülebilir. Neoplazilerle karışabilir. Kültürde üretilmeleri zordur. Bu nedenlerle doğru tanı genellikle ancak cerrahi işlemlerden sonra verilebilmektedir (4-8). Olgumuz akut apandisit bulgula- 
rı ile başvurmuş, tanı apendektomi spesmeninin incelenmesinden sonra verilebilmiştir.

Genellikle hastalık sinsi olarak ilerleyip süpürasyon oluşturmadan, yoğun fibrozis ile karakterize olması nedeni ile sıklıkla tümörlerle karıştırılabilir (6).

Bakterinin izolasyonu zordur. Kesin tanı histolojik olarak sülfür granüllerinin görülmesi ile konabilir. Sülfür granülleri histolojik kesitlerde veya eksudalarda organizma kümelenmeleri olarak görünür (9).

Aktinomiçes enfeksiyonlarında tedavide ilk tercih hala penisilindir. Penisilin alerjisi olan hastalar icin

\section{KAYNAKLAR}

1. Kaya D, Demirezen Ş, Beksac MS. Genital aktinomikoz gelişiminde rol oynayan faktorler. Klimik Derg. 2008; 21(Suppl. 1): 3-6.

2. Karagulle E, Turan H, Turk E, Kiyici H, Yildirim E, Moray G.Abdominal actinomycosis mimicking acute appendicitis. Can J Surg. 2008; 51(Suppl.5): E109-10.

3. Tsou KF, Yu CY, Hsu WH, Juan YH, Huang GS, Chang WC. Omental actinomycosis with abdominal wall invasion: a case report. Infect Dis Clin Pract. 2010; 18(Suppl. 5): 332-3.

4. Demirezen Ş, Beksac MS. Aktinomikoza genel bir bakış.Türkiye Klinikleri Tıp Bilimleri Dergisi. 2009; 29(Ek Sayı 2): 510-9.

5. Schmidt $P$, Koltai JL, Weltzien A. Actinomycosis of the appendix in childhood. Pediatr Surg Int. 1999; 15: 63-5.

6. Wali D, Sanchez J, Gilchirist B, Cash S, Anderson V, Ramenofsky M. Actinomycosis imitating an adrenal tumor. J Pediatr Surg. 2002; 37: 930-1.

7. Karateke F, Özyazıcı S, Menekşe E, Daş K, Özdoğan M. Unusual Presentations of Actinomycosis; Anterior Abdominal Wall and Appendix: Report of Three Cases. Balkan Med J. 2013; 30: 315-7. tetrasiklin, eritromisin, doksisiklin, klindamisin, imipenem, seftriakson ve siprofloksasin kullanılabilecek diğer ilaclar olarak bildirilmektedir (10). Tanı almayan olgularda cerrahiden aylar hatta yıllar sonra yaygın intraabdominal aktinomikozis gelişebilmektedir $(11,12)$.

Sonuç olarak, klinik özellikleri ayırdedici olmadığından tanı çoğu zaman cerrahi materyalin incelenmesi ile konur. Akut apandisit olgularında da aktinomiçes akla gelmelidir. Ameliyat sonrası sekonder enfeksiyon gelişmesi riskine karşı uygun antibiyoterapi ile tedavi edilmelidir.

8. Sung HY, Lee IS, Kim SI, Jung SE, Kim SW, Kim SY. Clinical features of abdominal actinomycosis: a 15-year experience of a single institute. J Korean Med Sci. 2011; 26: 932-7.

9. Russo AT. Agents of Actinomycosis. In: Mandell, Bennet, Dolin (eds). Principles and Practice of Infectious Diseases. 6thed. Churchill Livingstone; 2005, p. 2925-34.

10. Hocaoğlu B, Fikretler M, Aras A, Gurkaynak SG. Penisilin G ile Tedavi Edilen Abdominal Duvara Invaze Omental Aktinomikoz: Bir Olgu Sunumu. Klimik Derg 2011; 24(Suppl.2): 135-7.

11. Castillenti TA, Conklin CR. Actinomycosis: an unusual complication following appendicitis. J Am Osteopath Assoc. 1990; 90: 269-73.

12. Wagenlehner FM, Mohren B, Naber KG, Männl HF. Abdominal actinomycosis. Clin Microbiol Infect. 2003; 9: 881-5. 